\title{
THE IMPACT OF PEER ASSESSMENT ON STUDENTS' RECOUNT TEXT
}

\author{
Nur laili Indasari \\ Universitas Negeri Surabaya \\ nurindasari16070835068@mhs.unesa.ac.id \\ Oikurema Purwati \\ Universitas Negeri Surabaya \\ pungki_unesa@yahoo.co.id \\ Syafi'ul Anam \\ Universitas Negeri Surabaya \\ syafiul.anam@unesa.ac.id
}

\begin{abstract}
Peer Assessment is one of the alternative methods to enhance the students' motivation and ability in writing. Providing feedback is the goal of peer assessment. It is not an easy task as it is required an ability to deliver the feedback critically and competence to master the knowledge of writing. Therefore, the present study is going to explore the impact of giving feedback in the peer assessment process on students' recount text and to acknowledge the students' challenges while giving and receiving feedback in that process. Qualitative study assisted the researcher to get the data. The university students in the second semester became the subjects of the study. Documents and interviews were techniques to collect the data. The results revealed that the students' first draft and the last draft of recount text got improvements mainly on the aspect of grammar. Meanwhile, most students' challenges while giving and receiving feedback in the process of peer assessment were the aspect of psychology and the knowledge of grammar. In conclusion, the process of peer assessment which involves giving and receiving feedback provides a positive impact on the students' recount text and the challenges which are faced by the students can be used as inputs for the lecturer in teaching.
\end{abstract}

Keywords: Challenges, feedback, peer assessment, recount text

\section{A. INTRODUCTION}

$\mathrm{F}$

or English as a Foreign Language (EFL) learners, writing is considered to be a difficult skill. There are some reasons for claiming it. Firstly, Klimova (2014) states that writing is one of the most complicated language skills because of the students' lack of motivation and negative attitude toward the Foreign Language (FL). Secondly, writing is a skill which combines various elements such as grammatical and rhetorical elements (Eksan, 2004). Thirdly, Mukminatien (as cited in Eksan, 2004), states that writing requires not only the writer's linguistic competence but also communicative competence.

Traditionally, the model of learning is teacher-centered so it makes the students less involved in the teaching and learning process. The students should be given a chance to do an assessment for their own work or their peer's work. Therefore, implementing Peer Assessment (PA) can directly involve the students in the teaching and learning process. They can think and share their ideas with their friends. 
PA is a kind of assessment which asks the students to assess other students' work (Rosa et al., 2016). The assessment gives not only a score but also evaluative feedback to a work (Lin, 2018). Providing feedback is the goal of PA (Topping, 2009). In practice, PA can develop students' understanding of the learning materials as well as improve their meta-cognitive skills (Ballantyne et al., 2002; Malehorn, 1994). Brown et al. (1996) also claimed that an understanding of the importance of organization, coherence, and draft in the students' work can be developed through PA. Through PA, correct answers are provided and errors can be identified by the students.

In the implementation of PA, students as assessors of their peer's work may have different skills so some problems can appear in its use such as the reliability and the validity of the assessment. Although a peer assessor has less skill at assessment, with more training in the assessment, he or she can produce a reliable and valid assessment than a teacher (Topping, 2009). Moreover, the students' capability and psychology in assessing peer's writing must be paid attention. The previous studies found that the students lacked confidence in delivering their opinion or feedback in the process of PA because of their capability in assessing their peers' writing (Cheng and Warren, 2005; Topping, 2003; Zhao, 2018). To overcome these problems, the teacher should design the instrument well (Ohland et al., 2012). Defining the criteria of assessment together with the students and asking multiple raters can also be the solution to those problems.

Related to the implementation of PA in the teaching of writing, some researchers conducted studies on it (Azarnoosh, 2013; Birjandi and Siyyari, 2010; Puegphrom and Chiramanee, 2011; Suzuki, 2008; Xiao and Lucking, 2008). The results of those previous studies revealed that PA gave a better improvement in the students' writing performance than any other assessments. Most participants in the previous studies also showed positive responses to the implementation of PA in writing activities. The results showed that it could give improvement to their writing. However, the previous researchers merely compared the results of students' writing which were assessed by their peers with their teacher. There were only a few studies which analyzed in details the improved aspects in the students' writing from the first draft to the last draft. Subsequently, there were only a few studies which analyzed the challenges faced by the students while giving and receiving feedback in the PA process. A study was conducted by Wang (2014). He investigated the students' perceptions of peer feedback, the students' drafts, and students' concerns with interpersonal relationship. Therefore, it is required a study to analyze in details the changes on the students' drafts after getting feedback from their peer and to find out the challenges faced by the students in the PA process. 


\section{B. REVIEW OF LITERATURE}

\section{Peer assessment}

Peer assessment is a method which requires the students to give either feedback or grades (both) to their peers on a product or a performance based on the criteria of that product (Falchikov, 2007). Topping (2009) also states that PA is a device for students to think and to specify the point, the rate, or the quality of a product or performance of other students. PA is also defined as "an educational arrangement where students judge a peer's performance quantitatively and/or qualitatively and which stimulates students to reflect, to discuss, and to collaborate" (Strijbos and Sluijsmans, 2010, p. 265).

PA becomes one of the best types of formative assessment (Brown, 2004). Formative peer assessment happens through the development of student learning activities. The students can improve their writing ability by assessing and editing their own and peer's writing. Therefore, PA is an alternative method which can be applied for writing activities. It involves the students' participation in the learning process. They provide not only quantitative mark during the learning process but also detailed feedback information about strengths and weaknesses (Topping et al., 2000).

Providing feedback to learners is the goal of peer assessment (Topping, 2009). Kearsley (2000) claimed that feedback from friends is helpful because it is from their point of view rather than an expert's feedback. However, the students must be reminded to provide constructive comments and given clear guideline in giving feedback to their peer's writing. In the process of PA, there are three key elements named Feedback Giver (FG), Feedback Content (FC), and Feedback Receiver (FC). Firstly, FG is a student who provides feedback or gives comment. Secondly, FC is the comment given by FG. Thirdly, FR is a student who receives the feedback.

\section{Types of feedback}

According to Cheng et al. (2015), there are three types of feedback dealing with the contents: affective, cognitive, and metacognitive gains. Affective feedback means emotional gains such as praising comments (supporting) or negative messages criticizing peer's work (opposing). Cognitive feedback refers to clarification or expansion of the problems recognized or ideas given. There are three kinds of this feedback; direct correction, personal opinion, and guidance. First, the direct correction means that the students' feedback focuses on the correctness of the work such as matching the requirements of the assignment or concerning about a technical problem of the writing format. Second, personal opinion is feedback on general advice or personal opinion without indicating concrete directions to revise. Third, guidance means the feedback containing concrete suggestions, concepts, or approaches to 
improve the work. Then, metacognitive feedback comprises two categories: evaluating and reflecting. Evaluating means feedback messages about verification of knowledge, skills or selected strategies. Meanwhile, reflecting deals with challenging the writer to reflect or think the work thoroughly.

\section{Challenges of peer assessment}

The important cases that must be concerned with the method of peer assessment are related to the students' capacity to assess their peers' writing fairly and objectively. These may happen because of the lack of student's proficiency in assessment and the tendency of subjective marking (Carvalho, 2013). To overcome these cases, the teacher should design the instrument well (Ohland et al., 2012). It can be done by defining the criteria for assessing together with the students so that the feedback which is received has value for students in learning.

\section{Recount text}

The purpose of a recount is to restructure past experiences by retelling past events in chronological order (Hyland, 2003). This study focuses on the personal recount so that it includes the writer's feeling and experience about the events. The structures of this genre are orientation, a series of events, and reorientation. The orientation gives the readers information about who, what, when, and where (Knapp and Watkins, 2005). Then, a series of events are written in the order. The last, personal comment or statement about the events is stated. The linguistic features in recount text contain; (1) use of nouns and pronouns to identify people, animals, or things involved; (2) use of action verbs to refer to events; (3) use of past tense to locate events in relation to the writers' time; (4) use of conjunctions and temporal connectives to sequence the events; (5) use of adverbs and adverbial phrases to indicate place and time; and (6) use of adjectives to describe nouns (Hyland, 2003).

\section{METHOD}

\section{Respondents}

In this study, qualitative research design was conducted. The goal of qualitative research is to obtain a better understanding of human behavior and experience (Bogdan and Biklen, 2007). This design is appropriate to describe the results of students' recount text from the first to the last draft following the given feedback and to find the challenges faced by the students in the PA process. The results of the present study were descriptive data which meant that they were explained in the form of words rather than numbers.

This study was conducted in a city in Indonesia. The participants of the first and second objective were different. They were undergraduate students in the second semester. For the first 
research objective, ten students' texts were analyzed. Each text was given feedback by three students which were called FGs. They were from a different level of English skill; good, moderate, and low level. They were expected to learn each other. One student could assess two texts. Thus, for the second research objective, ten students who got feedback on their writing were interviewed related to their challenges while receiving feedback and sixteen participants (FG) were interviewed related to their challenges while giving feedback in the process of PA.

\section{Instruments}

For the first research objective, documents (the students' writings) were used to collect the data. The students' first and last draft of recount text and also the given feedback were the instruments for the first research objective. It was conducted to acknowledge the results of students' writings following up the given feedback in the PA whether there was progress or not on them. They were analyzed by using a rubric adapted from Hyland (2003).

A series of questions was the instrument for the second research objective. Semi-structured interview and open-ended questions were conducted to find out the students' challenges while giving and receiving feedback in PA. There were seven questions. Those were about the difficulty in analyzing the structures, the difficulty in analyzing the grammar, the students' feeling while giving feedback, the difficulty in receiving written English feedback, the difficulty in revising the draft, the students' opinion of multiple feedback givers, and the type of expected feedback .

\section{Procedures}

In this study, there were two procedures to collect the data. The first was document analysis. The researcher collected the first drafts. The feedback given by peers and the improvement on the students' drafts were analyzed then. Those were conducted until the last draft. From these, it could be acknowledged what aspects were improved on the students' writing after getting feedback from peers.

The second data collection procedure was an interview. It was conducted face to face. Firstly, the researcher proposed seven questions to the students. The students had to respond the questions one by one then. While conducting interview, the researcher recorded and noted the response.

\section{Data analysis}

Data analysis technique is the process of analyzing and arranging the collected data to enable the researchers to come up with findings (Bogdan and Biklen, 2007). The researchers adopted the model which is proposed by Miles et al. (2014) to study and to analyze the collected data. The steps to analyze the data are: 


\section{Data condensation}

For the first research objective, the data were in the form of documents. The data were obtained through students' writing. The students' first draft and last draft and also the given feedback were analyzed. Content, generic structures, and language features are the aspects which are analyzed. Coding was used to write the students' names. For example, S1 wrote her experience of having a holiday with her family. Then, the given feedback was about grammar so that the improved aspect in the last draft was on the language features especially on grammar.

For the second research objective, the data were got from the students' responses. Three questions deals with the students' difficulties when analyzing the structures, grammar, and the students' feeling while giving feedback to their peer. These questions were proposed to FG. Four questions related to the difficulties while receiving feedback in English and revising the drafts, the students' opinion of getting feedback from three students, and the expected feedback from their peers. From the result of the interview, the students' responses toward the challenges while giving and receiving feedback in the peer assessment were analyzed. The results of analysis were categorized based on the students' responses.

\section{Data display}

First of all, the students' drafts were analyzed based on rubric adapted from Hyland (2003) to be analyzed the content, structures, and language. See Appendix for the rubric. Then, the given feedback was analyzed to be identified how significant the given feedback on the errors found from the first to the last draft. From these, it could be acknowledged what aspects were improved in the last draft. The reduced data of the first research objective were displayed in the form of a table by showing the improved aspects from the first to the last draft.

The data of the second research objective were displayed in the form of tables too. Categorization was used to analyze the students' challenges while giving and receiving feedback in the PA process. It was determined based on the students' responses. The students' utterances became the proofs.

\section{Data verification}

In this step, it could be acknowledged that the results of a study between two research objectives were related to each other. The students' drafts could be analyzed whether there was a significant improvement or not depending on the given feedback. Then, the results of this study were compared with the findings of previous studies and or related theories. 


\section{FINDINGS AND DISCUSSION}

\section{The students' recount text}

To acknowledge the changes from the first draft to the last draft, the students' recount texts were analyzed. The results showed that there were several improved aspects of students' recount texts after getting feedback from their peer. They were described in the following table.

Table 1. Analysis of students' recount text

\begin{tabular}{cl}
\hline Number of students & \multicolumn{1}{c}{ The improved aspect } \\
\hline S1 & Grammar (pronoun) \\
S2 & Grammar (noun, tense), vocabulary \\
S3 & $\begin{array}{l}\text { Grammar (tense, pronoun, to- } \\
\text { infinitive), Mechanics (spelling) }\end{array}$ \\
S4 & Grammar (tense), Mechanics (spelling) \\
S5 & Grammar (tense, action verbs), \\
& Mechanics (punctuation, spelling) \\
S6 & Grammar (tense, preposition, gerund) \\
& Grammar (tense, preposition, action \\
S7 & capitalization) \\
& Grammar (tense) \\
S8 & Grammar (tense, noun phrase) \\
S9 & Grammar (tense, relative pronouns) \\
\hline
\end{tabular}

Based on Table 1, it could be analyzed that all students had an improvement in language features mainly grammar. For example, S8 made an error on the use of tense in the sentence we $d o$ and his peers gave him feedback to correct it so that it became we did. Then, one student had improvement in vocabulary. Vocabulary means the choice of word. S2 changed her word from stranger to weird after getting feedback from her peer. Afterward, three students had improvement in mechanics. It can be on the use of punctuation, spelling, or capitalization. For example, S5 corrected her spelling in the word respinsibility to responsibility. These happened because of the given feedback by the peer in the process of PA. It also seemed that the tendency of the given feedback was on grammar.

Basically, there were three students who did not have complete structures. For example, in orientation, they did not write some information about where and when the story happened. Then, one of them did not write her personal feeling of the events in reorientation. Nevertheless, their peer did not pay attention to the structures. They focused on the language features of recount text. 


\section{The Challenges while Giving and Receiving Feedback in the PA}

In the process of the interview, seven questions were proposed. Those were about the difficulty in analyzing the structures, the difficulty in analyzing the grammar, the students' feeling while giving feedback, the difficulty in receiving written English feedback, the difficulty in revising the draft, the students' opinion of multiple feedback givers, the type of expected feedback. The results of students' responses were presented in the following tables.

\section{The challenges while giving feedback}

There were sixteen participants but three students were absent at the process of the interview so that it was got thirteen students' responses. The first and second questions were related to the FG's difficulty in analyzing the structures and grammar of recount text.

Table 2. The difficulties in analyzing peer's recount text

\begin{tabular}{lll}
\hline Number of students & \multicolumn{1}{c}{ Structures } & Grammar \\
\hline S13 & Vocabulary & Tenses \\
S14 & Vocabulary & Tenses \\
S15 & Mastering of text & Tenses \\
S22 & Mastering of text & Tenses \\
S23 & Mastering of text & Tenses \\
S24 & Mastering of text & Psychologic \\
S26 & Mastering of text & al aspect \\
S28 & Mastering of text & Tenses \\
S29 & Vocabulary & Tenses \\
S30 & Mastering of text & Tenses \\
S31 & Mastering of text & Tenses \\
S33 & No difficulty & Psychologic \\
S34 & Mastering of text & al aspect \\
\hline
\end{tabular}

Based on Table 2, there were several difficulties faced by the students while analyzing the structures of recount text. Firstly, three students had difficulty in understanding what the writer wrote. Then, nine students stated that the writers were lack of understanding of recount text so that FG was difficult to find out the structures of recount text. The last, one student stated that he did not find any difficulty analyzing the structures of recount text. The following was the excerpt from one of the participants' responses related to the difficulty in analyzing the structures of recount text.

Interview 1

I: "What is the difficulty when you analyze the structures of your peer's recount text?" 
P: "I think there is no difficulty when analyze them" (S33, turn 4).

Subsequently, from the side of grammar, there were eleven students had difficulty in tenses. It happened to both sides, FG and FR. They sometimes forgot the pattern of tense and the writer used the wrong tense. Then, there were two students felt afraid of making a mistake and had a lack of confidence in analyzing the grammar. The following was an excerpt from one of the participants' responses related to the difficulty in analyzing grammar.

Interview 2

I: "Ok. Now, what is the difficulty when you analyze the grammar?"

P: "I am afraid of making mistake but we can correct each other" (S24, turn 8).

The second challenge was about the students' feeling while giving feedback to peer's writing. The following table was the results of the interview with the participants.

Table 3. The students' feeling while giving feedback

\begin{tabular}{ll}
\hline $\begin{array}{l}\text { Number of } \\
\text { students }\end{array}$ & \multicolumn{1}{c}{ The students' feeling } \\
\hline S13 & Capability \\
S29 & Capability \\
S33 & Capability \\
S14 & Psychological aspect \\
S15 & Psychological aspect \\
S22 & Psychological aspect \\
S23 & Psychological aspect \\
S24 & Psychological aspect \\
S26 & Psychological aspect \\
S28 & Getting the advantage \\
S30 & Getting the advantage \\
S34 & Getting the advantage \\
S31 & Not interested
\end{tabular}

In Table 3, the students' feedback while giving feedback to their peer was various. Three students felt that they did not know how to analyze peer's writing. It meant that they still felt difficulty while analyzing peer's writing. Then, six students' responses showed that there was an aspect of psychology which influenced them while giving feedback. It could be a feeling of anxiety, motivation, and self-esteem. One of these must happen when someone gave his or her opinion on peer's work. For example, S14 felt afraid of making a mistake while giving feedback to peer's writing. However, S26 felt that there was self-esteem in herself if she could find errors in her peer's writing. In addition, three students stated that they got benefits while giving 
feedback such as they could learn from their peer's error and could improve their writing. The last, one student stated that he was not interested in giving feedback because he was not interested in the topic discussed. The following was one of the results of the interview with the students.

Interview 3

I: "What's your feeling when you have to give feedback to your peer's writing?"

P: "I could find the lack of my friend's recount text so I can improve my sentence" (S28, turn 10).

\section{The challenges while receiving feedback}

Receiving written feedback is regarded as a challenge in the process of PA. It will not only influence the students' ability in revising their draft but also will influence the students' confidence and motivation in learning. The first challenge which was faced by FR was about the written feedback received. There were ten students' writings which were analyzed so that there were ten students who were interviewed. However, two students were absent in the process of interview. The following table was the results of the interview on that aspect.

Table 4. The challenges in receiving written feedback

\begin{tabular}{lll}
\hline Number of students & The challenges & \\
\hline S1 & Language & \\
S2 & Language & \\
S3 & Language & \\
S4 & Language & \\
S5 & Language & \\
S6 & Language & \\
S7 & No difficulty & \\
S8 & The benefits of English \\
\hline
\end{tabular}

In Table 4, six students stated that they had difficulty from the side of language. It means that they had difficulty in understanding the given feedback by their peer. Sometimes, they required to translate the written English feedback into Indonesian. However, one student stated that she did not have a problem with the given feedback because it used simple language so that it was understandable and. In another side, one student stated that she got the benefits of receiving written English feedback because it could increase their motivation in learning English. The following excerpt showed one of the students' responses related to the hindrance while receiving written English feedback.

Interview 4 
I: "What is the difficulty when you get written feedback in English?"

P: "I enjoy it because it makes me learn more about English." (S8, turn 18)

Subsequently, after analyzing the students' drafts there were found errors in the final draft even though they got feedback from their peer. It indicated that the students still had difficulty in revising their drafts. The following table showed the students' responses to that difficulty.

Table 5. The difficulties in revising the drafts

\begin{tabular}{ll}
\hline Number of students & \multicolumn{1}{c}{ The difficulties } \\
\hline S1 & Grammar \\
S2 & Grammar \\
S3 & Grammar \\
S4 & Grammar \\
S5 & The inconsistency of the \\
S6 & given feedback \\
S7 & No difficulty \\
S8 & No difficulty \\
\hline
\end{tabular}

In Table 5, it showed that four students had a problem in the case of grammar. They still had difficulty to change the verb into simple past tense. Then, one student stated that there was inconsistency from the given feedback. It means that the given feedback changed from the first to the final draft. Last, three students stated that they did not have difficulty in revising the draft because the FG gave explicit correction. The following excerpt showed one of the students' responses to that aspect.

Interview 5

I: "What is the difficulty when you revise the draft?"

P: "I am still confused to change the verbs into verb two." (S2, turn 24)

In the process of PA, one writer was given feedback by three students. To get the students' responses toward the use of multiple feedback givers in this study, the interview was conducted. In this case, feedback receivers were interviewed. The results were in the following table.

Table 6. The students' opinion of multiple feedback givers

\begin{tabular}{ll}
\hline Number of students & \multicolumn{1}{c}{ The students' opinion } \\
\hline S1 & Positive \\
S2 & Positive \\
S3 & Positive \\
S4 & Positive \\
S5 & Positive \\
S6 & Positive \\
S7 & Negative \\
S8 & Negative \\
\hline
\end{tabular}


In Table 6, six students showed positive responses to the use of multiple feedback givers in the process of PA. Errors in writing would be more identified by implementing it. Then, there were two students gave negative responses. They stated that it was an ineffective way because each student had a different opinion and it was still found errors in giving feedback. The following excerpt was one of the results of the interview.

Interview 6

I: "What's your opinion when three students gave feedback to one writer?"

P: "It's very good because we have different ability" (S1, turn 28)

The last question related to the difficulties which were faced by the students while receiving feedback was the expected feedback in the PA process. By looking at the content of the given feedback in the process of PA, affective and cognitive were two types of feedback given by peers. The results of the interview on the types of expected feedback in the PA process were explained in the following table.

\begin{tabular}{ll}
\multicolumn{2}{c}{ Table 7. The expected feedback } \\
\hline $\begin{array}{l}\text { Number of } \\
\text { students }\end{array}$ & The expected feedback \\
\hline S1 & Direct correction \\
S2 & Direct correction \\
S3 & Direct correction \\
S4 & Direct correction \\
S5 & Guidance feedback \\
S6 & Guidance feedback \\
S7 & Guidance feedback \\
S8 & Guidance feedback \\
\hline
\end{tabular}

Based on Table 7, four students expected direct feedback which meant that they did not only want the FG to show their errors in writing but also they wanted the correct forms. In another side, four students expected guidance feedback which meant they only wanted the FG to give concrete suggestion about the errors. The following excerpt showed one of the results of the interview on the expected feedback.

Interview 7

I: "What types of feedback that you want from your peer?"

P: "Choose clear explanation and also correct forms so I can improve the errors." (S2, turn 28) 
Based on the results of analysis on the students' recount text after getting feedback in the PA process, the data indicated that they got improvement from the first draft to the last draft. The finding is consistent with the previous studies on the impact of PA on students' performance (Birjandi and Siyyari, 2010; Faudi, 2016; Iraji et al., 2016; Misianto, 2014; Puegphrom and Chiramanee, 2011; Suzuki, 2008; Xiao and Lucking, 2008). Moreover, the feedback given by peers can reduce errors in writing. it is relevant to the previous study (Topping, 2003). He claims that feedback can reduce errors and have a positive impact on learning when it is received positively. The reduced errors are mostly on the aspect of grammar. However, it is not the only characteristic of writing improvement and perhaps it cannot be the best measure of good writing. It is stated by Hyland (2003). Grammar is important, but the students also need to pay attention to the coherence and layout of their writing.

Related to the challenges faced by the students while giving and receiving feedback, mastering of grammar becomes the main cause. It means that their capacity in assessing peer's work lacks. They also have difficulty in revising their draft because of their knowledge of grammar. These findings are in line with Hyland (2003). He states that students generally have difficulties, particularly an insufficient grasp of grammar, their main problem in writing. In addition, the psychological aspect such as expression of qualm happens in delivering feedback. It is relevant to the previous study (Brown et al., 2009). They state that the students still have a qualm about their capability to assess each other.

\section{E.CONCLUSION}

Peer Assessment (PA) method in this study demonstrates that the students' capability in assessing peer's writing still lacks. It is identified by the given feedback during the process of PA and the results of interview. In delivering the feedback, the students more focus on grammar. Meanwhile, the lecturer has explained that there are three aspects which can be analyzed in recount text such as content, generic structures, and language features. As a result, PA provides a better improvement in the students' writing, the given feedback can reduce the errors however it is not significant. The errors are still found on the aspect of content and structures. To overcome this, the lecturer should provide clear guidelines for students in assessing their peer's writing.

Another concern with the PA is related to the challenges while giving and receiving feedback. The results of interview indicate that in analyzing peers' writing, the students still have difficulty in the case of grammar and have anxiety while giving feedback. Subsequently, the students have positive response toward the implementation of PA however they still have 
difficulty in revising the drafts because of their capability. The students should acknowledge that not only focusing on grammar but also mastering of the text are important for them in order to be able to provide valuable feedback to peer's writing.

\section{REFERENCES}

Azarnoosh, M. (2013). Peer Assessment in an EFL Context: Attitudes and Friendship Bias. Language Testing in Asia, 3 (11), 1-10.

Ballantyne, R., Hughes, K., \& Mylonas, A. (2002). Developing Procedures for Implementing Peer Assessment in Large Class Using an Action Research Process. Assessment \& Evaluation in Higher Education, 27 (5), 427-441.

Birjandi, P \& Siyyari, M. (2010). Self-Assessment and Peer-Assessment: A Comparative Study of Their Effect on Writing Performance and Rating Accuracy. IJAL, 13 (1), 23-42.

Bogdan, R. C. \& Biklen, S. K. (2007). Qualitative Research for Education: An Introduction to Theory and Method ( $5^{\text {th }}$ ed.). USA: Pearson.

Brown, G. T. L., Irving, S. E., Peterson, E. R., \& Hirschfeld, G. H. F. (2009). Use of InteractiveInformal Assessment Practices. New Zealand Secondary Students' Conceptions of Assessment. Learning \& Instruction, 19 (2), 97-111.

Brown, H. D. (2004). Language Assessment: Principles and Classroom Practices. Longman.

Brown, S., Race, P., \& Smith, B. (1996). 500 Tips on Assessment. London: Kogan Page.

Carvalho, A. (2013). Students' Perception on Fairness in Peer Assessment: Evidence from a Problem-Based Learning Course. Teaching in Higher Education, 18 (5), 491-505.

Cheng, K. H., Liang, J. C., \& Tsai, C. C. (2015). Examining the Role of Feedback Messages in Undergraduate Studnets' Writing Performance during an Online Peer Assessment Activity. Internet and Higher Education, 25, 78-84.

Eksan, R. (2004). Improving Writing Ability of the Second Year Students of SLTPN 18 Malang through Process Writing. Thesis Unpublished. Malang: Postgraduate Program of State University of Malang.

Falchikov, N. (2007). The Place of Peers in Learning and Assessment. New York: Routledge.

Faudi. (2016). The Implementation of Peer Assessment Technique in Teaching Writing. English Education Journal (EEJ), 7 (3), 402-414.

Harmer, J. (2004). How to Teach Writing. England: Pearson Longman.

Hyland, K. (2003). Second Language Writing. USA: Cambridge University Press. 
Iraji, H. R., Enayat, M. J., \& Momeni, M. (2016). The Effects of Self- and Peer Assessment on Iranian EFL Learners' Argumentative Writing Performance. Theory and Practice in Language Studies, 6 (4), 716-722.

Kearsley, G. (2000). Online education: Learning and teaching in cyberspace. Belmont, CA: Wadsworth.

Klimova, B. F. (2014). Constraints and Difficulties in The Process of Writing Acquisition. Procedia-Social and Behavioral Sciences, 122, 433-437.

Knapp, P. \& Watkins, M. (2005). Genre, Text, Grammar: Technologies for Teachhing and Assessing Writing. Australia: University of New South Wales Press Ltd.

Lin, G. Y. (2018). Anonymous versus identified peer assessment via a Facebook-based learning application: Effects on quality of peer feedback, perceived learning, perceived fairness, and attitude toward the system. Computers \& Education.

Malehorn, H. (1994). Ten Measures Better than Grading. The Clearing House, 67(6), 323-324.

Miles, M. B., Huberman, A. M., \& Saldana, J. (2014). Qualitative Data Analysis: A Methods Sourcebook $\left(3^{\text {rd }}\right.$ ed.). USA: SAGE.

Misianto. (2014). Improving Students' Ability in Writing an Essay through Peer-Assessment Strategy at the Fifth Semester in Cipta Wacana Christian University of Malang. Jurnal Ilmiah Bahasa dan Sastra, 1 (1), 37-48.

Ohland, M. W., Loughry, M.L., Woehr, D. J., Bullard, L. G., Finelli, C. J., .. Schmucker D. G. (2012). The Comprehensive Assessment of TeamMember Effectiveness: Development of a Behaviorally Anchored Rating Scale for self-and Peer Evaluation. The Academy of Management Learning and Education, 11 (4), 609-630.

Puegphrom \& Chiramanee. (2011). The Effectiveness of Implementing Peer Assessment on Students' Writing Proficiency. Proceedings of the Third International Conference on Humanities and Social Sciences (pp. 1-17). Songkla UniversityPutra, Kristian A. (2014). The Implication of Curriculum Renewal on ELT in Indonesia. Parole, 4 (1), 63-75.

Rosa, S. S., Coutinho, C. P., \& Flores, M. A. (2016). Online Peer Assessment: Method and Digital Technologies. Procedia-Social and Behavioral Sciences, 228, 418-423.

Strijbos, J. W. \& Sluijsmans, D. (2010). Unraveling Peer Assessment: Methodological, Functional, and Conceptual Developments. Learning and Instruction, 20, 265-269.

Suzuki, M. (2008). Japanese Learners' Self Revisions and Peer Revisions of Their Written Compositions in English. TESOL Quarterly, 42 (2), 209-233.

Topping, K. J., Smith, E. F., Swanson, I., Elliot, A. (2000). Formative Peer Assessment of Academic Writing between Postgraduate Students. Assessment \& Evaluation in Higher Education, 25 (2), 149-169. 
Nurlaili Indasari, Ouikurema purwati, Syafi'ul Anam The Impact of Peer.....

Topping, K. (2003). Self and Peer Assessment in School and University: Reliability, Validity, and Utility. Optimizing New Modes of Assessment: In Search of Qualities and Standards, 55-87.

Topping, K. J. (2009). Peer Assessment. Theory Into Practice, 48 (1), 20-27.

Wang, W. (2014). Students' Perceptions of Rubric-Referenced Peer Feedback on EFL Writing: A Longitudinal Inquiry. Assessing Writing, 19, 80-96.

Xiao, Y. \& Lucking, R. (2008). The Impact of Two Types of Peer Assessment on Students' Performance and Satisfaction within a Wiki Environment. Internet and Higher Education, 11, 186-193.

Zhao, H. (2018). Exploring Tertiary English as Foreign Language Writing Tutor's Perceptions of the Appropriateness of Peer Assessment for Writing. Assessment \& Evaluation in Higher Education. Routledge: Taylor \& Francis Group. 


\section{APPENDIX}

\section{Rubric for Recount Text Adapted from Hyland (2003)}

\begin{tabular}{|c|c|c|}
\hline Content & Generic structures & Language features \\
\hline $\begin{array}{l}\text { - Events are explicitly } \\
\text { stated and } \\
\text { documented } \\
\text { - Personal comment } \\
\text { rounds off the events }\end{array}$ & $\begin{array}{l}\text { - Orientation gives all essential } \\
\text { information (who was involved, } \\
\text { what happened, when it } \\
\text { happened, and where it } \\
\text { happened). } \\
\text { - A series of events are written in } \\
\text { chronological order. } \\
\text { - Evaluation or reorientation } \\
\text { completes the events (the writer's } \\
\text { feeling is coherent with the } \\
\text { events) }\end{array}$ & $\begin{array}{l}\text { - Excellent control } \\
\text { of language } \\
\text { - Excellent use of } \\
\text { vocabulary and } \\
\text { grammar (few } \\
\text { errors on the use of } \\
\text { noun and } \\
\text { pronouns, action } \\
\text { verbs, past tense, } \\
\text { conjunction and } \\
\text { temporal } \\
\text { connectives, } \\
\text { adverbs, and } \\
\text { adverbial phrases, } \\
\text { and adjectives ) }\end{array}$ \\
\hline $\begin{array}{l}\text { - Events are fairly } \\
\text { stated } \\
\text { documented } \\
\text { - There are some } \\
\text { personal comments } \\
\text { on events }\end{array}$ & $\begin{array}{l}\text { - Orientation is fairly well- } \\
\text { developed (only } 3 \text { of } 4 \text { W } \\
\text { questions are mentioned in the } \\
\text { text) } \\
\text { - Most events mentioned } \\
\text { - Largely chronological and } \\
\text { coherent } \\
\text { - Evaluation or reorientation } \\
\text { completes the events (the writer's } \\
\text { feeling is coherent with the } \\
\text { events) }\end{array}$ & $\begin{array}{l}\text { - Excellent control } \\
\text { of language } \\
\text { - Excellent use of } \\
\text { vocabulary and } \\
\text { grammar (several } \\
\text { errors on the use of } \\
\text { noun and } \\
\text { pronouns, action } \\
\text { verbs, past tense, } \\
\text { conjunction and } \\
\text { temporal } \\
\text { connectives, } \\
\text { adverbs, and } \\
\text { adverbial phrases, } \\
\text { and adjectives) }\end{array}$ \\
\hline $\begin{array}{l}\text { - Events are simply } \\
\text { stated } \\
\text { documented } \\
\text { - personal comment is } \\
\text { inadequate on events }\end{array}$ & $\begin{array}{l}\text { - Orientation gives some } \\
\text { information (only } 2 \text { of } 4 \text { W } \\
\text { questions are mentioned in the } \\
\text { text) } \\
\text { - A series of events are partly } \\
\text { coherent } \\
\text { - Evaluation or reorientation is } \\
\text { attempted although it is not } \\
\text { coherent }\end{array}$ & $\begin{array}{l}\text { - inconsistent } \\
\text { language control } \\
\text { - lack of variety in } \\
\text { grammar and } \\
\text { vocabulary } \\
\text { (frequent errors on } \\
\text { the use of noun } \\
\text { and pronouns, } \\
\text { action verbs, past } \\
\text { tense, conjunction } \\
\text { and temporal } \\
\text { connectives, } \\
\text { adverbs, and }\end{array}$ \\
\hline
\end{tabular}


Nurlaili Indasari, Ouikurema purwati, Syafi'ul Anam The Impact of Peer.....

\begin{tabular}{|c|c|c|}
\hline & & $\begin{array}{l}\text { adverbial phrases, } \\
\text { and adjectives) }\end{array}$ \\
\hline $\begin{array}{l}\text { - Events are not stated } \\
\text { and not recognized } \\
\text { - There is no personal } \\
\text { comment on events }\end{array}$ & $\begin{array}{l}\text { - Orientation is weak or missing } \\
\text { (only } 1 \text { of } 4 \mathrm{WH} \text { questions is } \\
\text { mentioned in the text) } \\
\text { - A series of events are incoherent } \\
\text { - Evaluation or reorientation is not } \\
\text { included based on the events.(the } \\
\text { writer's feeling is not related to } \\
\text { the events) }\end{array}$ & 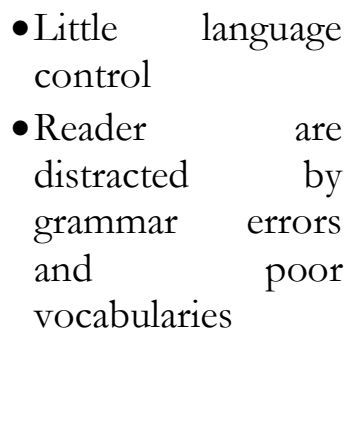 \\
\hline
\end{tabular}

